\title{
DIFFERENCES IN THE PERCEPTION OF SOCIAL SUPPORT BETWEEN THE YOUTH WITH INVALIDITY AND THE YOUTH WITHOUT INVALIDITY
}

\author{
Izeta Husić-Đuzić ${ }^{1}$ \\ Ševala Tulumović \\ Vesna Bratovčić
}

Original scientific paper

University of Tuzla, Faculty of Education and Rehabilitation Bosnia and Herzegovina

Received: 12.11.2017

Accepted: 27.12.2017

\begin{abstract}
The aim of this paper was to identify differences in the perception of social support for young people with and without disabilities in the age of 18-35 in the Tuzla Canton. The sample of examinees consists of two sub-classes. The first subsample is made of young people with disabilities, chronological age 18-35, both sexes $(N=50)$. The second subsample consists of young people with no disabilities, chronological age 18-35, both sexes $(N=50)$. The data obtained by the research were processed by the method of parametric and nonparametric statistics. The frequencies, percentages and measures of central tendency (arithmetic mean, standard deviation) are calculated. P-values were used to investigate the differences between the examined variables, and the variance analysis was used to investigate the significance of differences. The results of research on differences in the perception of social support among young people with disabilities and young people without disabilities show that there is a statistically significant difference in the most applied variables. Based on the results obtained in the case of youth with disabilities, it would be advisable to start with integration into social life at all levels.
\end{abstract}

Keywords: youth with disabilities, youth without disabilities, social support.

\section{INTRODUCTION}

There is a large number of people in Bosnia and Herzegovina with a different degree and type of disability who are trying to be accepted by the society. The wish of every young person is to be independent and successful in all aspects of life. In order to achieve such a thing, sufficiently stimulating environment, social support and family support are required (HusićĐuzić, 2016). Accessibility means that people with disabilities have access, on an equal basis like everyone else, to the physical environment, transportation means, information and communication technologies and systems, as well as other facilities and services.

\section{${ }^{1}$ Correspodence to:}

Ševala Tulumović, PhD, University of Tuzla, Faculty of Education and Rehabilitation Bosnia and Herzegovina

Univerzitetska 1, 75000 Tuzla, Bosnia and Herzegovina

Phone:387 35-320 673

E-mail address: sevala.tulumovic@untz.ba 
There are still tremendous obstacles in all these areas (Matković \& Načinović, 2015). The obligation of the society is to ensure that all people with disabilities are less likely to experience the consequences of disability by providing them with adequate health care, rehabilitation, safer environment and raising community awareness that is ready to provide support to people with disabilities Husić-Đuzić, 2016). A person with a disability is like every person with a different physical, intellectual or mental condition or illness that permanently disables the satisfaction of personal and social needs in everyday social and economic life (Žunić, 2001). In the past few decades, at least three predominant models in approaching the interrelated disability phenomenon are available, defining in this way the relationship between the community towards people with disabilities and the relation of people with disabilities to the phenomenon of disability and towards themself. (Zahirović, Čolić \& Jonjić, 2009). In order to achieve the basis for a standardized assessment of the functioning of a person, and its interaction with the environment, it is necessary to make a specification for each of the separate functions, activities and factors of the environment when there is no damage to the observed variable when the damage is mild, moderate, severe or complete (Strnad \& Benjak, 2010). The philosophy of independent life is the result of the movement of people with disabilities that issue the disability as a matter of human rights (Vučenović \& Mastikosi, 2011). Self-esteem for people with disabilities is defined by estimating their own capacity for functioning in the social environment (Omolayo, 2009). Activities of everyday life include tasks for which a person is regularly preparing or in addition to participating in his or her social roles and work in everyday life (Trombly, 1995). Managing social interactions is one of the most complex tasks that people do (Masty \& Schwab, 2006). Bratovčić and Galijašević (2015) state that the possession and use of social skills by young people with disabilities affects life and professional achievements and social relations.

\section{THE AIM OF THIS PAPER}

The aim of the paper is to identify differences in the perception of social support between young people with disabilities and young people without disabilities.

\section{WORK METHODS}

\section{Sample of respondents}

The sample of respondents consists of two subsamples. The first subsample was composed of young people with disabilities, chronological age 18-35 years, both sexes, 50 of them. The second subsample was made of young people with no disabilities, chronologically aged $18-35$ years, both sexes, 50 of them, selected by a random selection method from the territory of Tuzla Canton.

\section{Method of conducting research}

The study was conducted over a period of two months during which field testing was carried out. Each respondent responded independently after receiving the instructions from the interviewer. The respondents were asked to express their agreement or disagreement, ie degree of agreement or disagreement with the paragraphs expressed in the statements. Young people with disabilities were interviewed individually. The time that was foreseen for an interview with each respondent was 15-25 minutes. Young people without disabilities are surveyed in groups. The estimated time required to complete the questionnaire provided by this survey is 15 minutes. All respondents are familiar with the purpose of the survey and are informed about how to complete the questionnaire.

\section{Measuring instruments}

For this research, a Multidimensional Scale of Perceived Social Support was used (Multidimensional Scale of Perceived Social Support - Zimet, Dahlem, Zimet \& Farley, 1988).

\section{Methods of data processing}

The data obtained by the research were processed by the method of parametric and nonparametric statistics. The frequencies, percentages and measures of the central tendency (arithmetic mean, standard deviation) are calculated. P-values were used to investigate the differences between the examined variables, and the variance analysis was used to investigate the significance of differences. The data is shown in tabular form. The data was processed in the SPSS 16 statistical package for Windows. 


\section{RESULTS}

In order to assess the perception of social support for young people with disabilities, 18 variables related to the perception of family and friend support were applied. Ta- ble 1 shows the results of the research, in terms of level of agreement or non-agreement with the offered statements and differences in responses, or perception of social support, between young people with disabilities and young people without disabilities.

Table 1 Structure of respondents according to the perception of social support

\begin{tabular}{lcccc}
\hline \multirow{2}{*}{ Claim } & \multicolumn{2}{c}{$\begin{array}{c}\text { Control } \\
\text { I agree }\end{array}$} & \multicolumn{2}{c}{$\begin{array}{c}\text { Experimental } \\
\text { I disagree }\end{array}$} \\
\cline { 2 - 5 } & $\mathbf{f}$ & $\mathbf{9}$ & $\mathbf{f}$ & $\mathbf{\%}$ \\
\hline I have a clear role in my family & 49 & 98.00 & 47 & 94.00 \\
I have a clear role among my friends & 50 & 100.00 & 45 & 90.00 \\
I feel family members understand me & 49 & 98.00 & 43 & 86.00 \\
I feel my friends understand me & 49 & 98.00 & 40 & 80.00 \\
When I talk to family members, I feel they listen carefully to & 49 & 98.00 & 43 & 86.00 \\
me & & & & \\
When I talk to my friends I feel they listen carefully to me & 48 & 96.00 & 39 & 78.00 \\
My family members help me to do things for me & 1 & 2.00 & 8 & 16.00 \\
My friends help me to do things for me & 1 & 2.00 & 8 & 16.00 \\
I'm active on social networks & 50 & 100.00 & 44 & 88.00 \\
\hline
\end{tabular}

The results of Table 1 clearly show that there is a statistically significant difference $(p<.05)$ in all applied variables, except for the first claim "I have a clear role in the family" $(p=.307)$. A greater percentage of the proposed allegations were recorded in care of young people without disabilities. The results of the research presented in Table 1 also point to the existence of statisti- cal significance regarding the activities of young people with disabilities in social networks compared to young people without disabilities.

Table 2 shows average values and deviations in relation to certain activities of respondents, such as socializing and dating with friends, telephone conversations, going to cultural and sporting events.

Table 2 Average values and measures of dispersion related to social life

\begin{tabular}{|c|c|c|c|}
\hline Questions & $\begin{array}{l}\text { Control group } \\
\qquad \mu \pm \sigma\end{array}$ & $\begin{array}{l}\text { Experimental group } \\
\qquad \mu \pm \sigma\end{array}$ & $\mathbf{p}$ \\
\hline $\begin{array}{l}\text { How many times have you been spending time with people who do not } \\
\text { live with you in the past month? }\end{array}$ & $8.12 \pm 4.41$ & $11.87 \pm 12.99$ & .057 \\
\hline $\begin{array}{l}\text { How many times have you been visiting friends or family for the past } \\
\text { month? }\end{array}$ & $6.32 \pm 2.40$ & $6.89 \pm 6.11$ & .540 \\
\hline $\begin{array}{l}\text { How many times in the past month have you been invited to go out } \\
\text { with your friends? }\end{array}$ & $7.40 \pm 3.30$ & $5.23 \pm 3.96$ & .004 \\
\hline $\begin{array}{l}\text { How many people in your environment can you count for help at any } \\
\text { time (apart from family members)? }\end{array}$ & $2.32 \pm 3.05$ & $4.85 \pm 10.07$ & .093 \\
\hline $\begin{array}{l}\text { How many times did you talk to someone over the phone in the past } \\
\text { month? }\end{array}$ & $20.10 \pm 8.16$ & $23.47 \pm 37.29$ & .535 \\
\hline How many times did you go to the movies last month? & $1.64 \pm 0.96$ & $0.81 \pm 1.57$ & .002 \\
\hline How many times did you go to the theater last month? & $1.78 \pm 1.43$ & $0.36 \pm 0.49$ & .000 \\
\hline How many times did you go to a sports event in the past month? & $2.28 \pm 1.80$ & $1.09 \pm 1.16$ & .000 \\
\hline $\begin{array}{l}\text { How many times did you visit the organization you are involved in the } \\
\text { past month? }\end{array}$ & $0.44 \pm 3.11$ & $5.23 \pm 10.85$ & .003 \\
\hline
\end{tabular}


According to the results obtained in Table 2 we conclude that there is a statistically significant difference $(\mathbf{p}<.05)$ in average values for the following variables-questions: „How many times in the past month have you been invited to go out with your friends?"; „How many times did you go to the movies last month?“; „How many times did you go to the theater last month?"; „How many times did you go to a sports event in the past month?"; „How many times did you visit the organization you are involved in the past month?" According to the results, it is evident that the average number of outings with friends, cinema, theater or sports events is statistically higher for young people with no disabilities compared to young people with disabilities. By contrast, the average number of visits to an organization involved is higher among young people with disabilities compared to young people without disabilities $(\mathrm{p}<.05)$.

\section{DISCUSSION}

The need and availability of support is a critically intervention factor in relation to social support and health. Perception of the need and availability of social support has a greater impact on health than the actual need and availability (Gibson, 1994). Some research shows that poor (community) support is a consequence of bad health, not weak social support (Parker et al., 1992). Poor social support and a social networking can bring a person into social isolation. This can result in physical symptoms that a person in an unadjusted way asks for help or attempts to attract the attention of others to him (Cohen, 1990). Support that young people with disabilities receive from friends and parents can be one of the drivers to a successful and independent lifestyle. Willing to be self-reliant, and not being supported by close family and people around them, are the barriers faced by young people with disabilities (Bratovčić \& Mehmedinović, 2015). Although the development of technology and access to the Internet enables and facilitates communication between people and the creation of wider social networks, however, social life on the Internet can not fulfill the needs of the person's support and social affiliation in quantitative or qualitative terms. Research related to the Internet's influence on mental health and the wealth of social relationships are contradictory. While others talk about the negative impact of the Internet on the mental health and social lives of its users (Bratovčić \& Mehmedinović, 2015), others (Rakić-Bajić, 2012) argue that the Internet has no negative impact on mental health unless there is already a psychopathological disorder or predisposition to develop addictive behavior. The research carried out by Bratovčić \& Mehmedinović (2015) suggests that young people with disabilities have fewer opportunities to develop social relationships, networks and social interaction with peers because social interaction is performed indirectly through parents, family members and, in particular, the internet. Also, young people with no disabilities, in relation to young people with disabilities, go out with friends more, visit a cinema, a theater or a sports event more often. By contrast, young people with disabilities in relation to young people without disabilities spend more time in the organizations they are involved in. The results indicate that the social life of young people with disabilities is mainly within the family and within the organizations of people with disabilities. Karacic (2012) states that social support does not always necessarily mean a positive experience, especially in the context of independence. Accepting help from other people can create some sense of addiction or inferiority in some, and that is when social support can be detrimental, as it does not allow social support recipients to develop their own resources to deal with stressful situations. The lack or insufficient development of social skills affects the social integration of young people with disabilities (Arsenović \& Pantelić, 2014).

\section{CONCLUSION}

Based on the results of the research itself, the following conclusion can be made:

The results obtained in this research show that there is a statistically significant difference in the perception of social support among young people with disabilities and young people without disabilities. The results show that young people with disabilities in relation to young people without disabilities have a poorer perception of social support in terms of feeling that people in their environment listen and respect their thinking and understand their needs. The results obtained also indicate that the social life of young people with disabilities is mainly within the family and within the organization of people with disabilities. 


\section{REFERENCES}

Arsenović, D. \& Pantelić, M. (2014). Impact of social skills development of people with disabilities on labor and social integration. Beograd: Lola Preduzetništvo.

Bratovčić, V. \& Mehmedinović, S. (2015). The path to independence. Report on the Investigation of Attitudes of Young People with Disabilities and their Families on the Rights and Opportunities of People with Disabilities in the Tuzla Canton. Project: Strengthening Capacity for Independent Living of People with Disabilities in Bosnia and Herzegovina. Tuzla: Information Center for People with Disabilities: Lotos.

Bratovčić, V. \& Galijašević, Z. (2015). Strengthening Capacity for Independent Living of People with Disabilities in Bosnia and Herzegovina - support program (peer support) Handbook for Trainers of Young People with Disabilities. Information Center „Lotos“, Tuzla.

Cohen, G. D. (1990). Psychopathology and mental health in the mature and elderly adult. San Diego: Academic press, 359-371.

Gibson, R. C. (1994). The age-by-race gap in health and mortality in the older population: a social science research agenda. The Gerontologist, 34, (4): 454-462.

Husić-Đuzić, I.(2016). Assessment of Success in Life Skills of Young People with Disabilities, Master's Degree. Faculty of Education and Rehabilitation of the University of Tuzla.

Karačić, S. (2012). Social support for adolescents with physical disability. Hrvatska, JAHR, 3(5): 219-243.

Matković, A., \& Načinović, L. (2015). Employment of people with disabilities. Employer's Manual, Republic of Croatia.

Masty, J., \& Schwab, Y. (2006). Changing the face of child mental health. NYU Child Study Centar: NY.
Omolayo, B. (2009). Effects of leadership styles on job related tension and psychological sense of comm unity in work organization: case study of four organization in Lagos State, Nigeria: Bangladesh.

Parker, M. G., Thorslund, M., \& Nordstrom, M. (1992). Predictors of mortality for the oldest old. A 4-year follow-up of community-based elderly in Sweden. Archives of Gerontology and Geriatrics, 14, 227-237.

Rakić-Bajić, G. (2012). Excessive use of the Internet, satisfaction with life and personality traits. 1, 119-131. State University of Novi Pazar.

Strnad, M., \& Benjak, T. (2010). International Classification of Functioning, Disability and Health. Zagreb: Medical Book.

Trombly, C. (1995). Occupational therapy for Physical Dysfunction. Baltimore: Maryland.

Vučenović, D., \& Mastikosa, O. (2011). Independent life of people with disabilities. Banja Luka. [cited] available from http://www.ho-partner.rs.sr/brosure/samostala_zivot.

Zahirović, S., Čolić, V., \& Jonjić, D. (2009). New approaches to disability: Inclusion and equal opportunities. The Directorate for Economic Planning of Bosnia and Herzegovina, the Federal Ministry of Labor and Social Policy, the Ministry of Health and Social Welfare of Republika Srpska. Sarajevo: Independent Humanitarian Affairs Bureau.

Zimet, G.D., Dahlem, N.W., Zimet, S.G., \& Farley, G.K. (1988). The Multidimensional Scale of Perceived Social Support. Journal of Personality Assessment 52: 30-41.

Žunić, Z. (2001). With professional rehabilitation to the 21 st century. State Institute for the Protection of the Family, Maternity and Youth. Zagreb: Ministry of Labor and Social Welfare. 